\title{
Impact of Globalization on Aggregate and Agricultural Employment in Pakistan
}

Moniba Sana ${ }^{1}$,Atif Ali Jaffri ${ }^{2}$, Asadullah Khan ${ }^{3}$

\begin{abstract}
This study has empirically investigated the impact of globalization on aggregate and agricultural employment in Pakistan for the data period 1986-2017. Globalization is proxied by variables trade openness, foreign direct investment, workers' remittances, and exchange rate. Other explanatory variables are real GDP, gender-based wage gap, and labor force. The study has applied Johansen' cointegration technique and Error Correction Model to estimate the long-run and short-run relationships. The findings of the study indicate that in the long-run trade openness has been negative whereas FDI has a positive effect on aggregate as well as agricultural employment in Pakistan during the data period. Interestingly, exchange rate and workers' remittances affect aggregate and agricultural employment differently. Another important finding is that real GDP and gender-based wage gap also deteriorate aggregate and agricultural employment in Pakistan. The study concluded that globalization in the form of trade openness has not supported employment whereas FDI enhanced employment in Pakistan. Policymakers need to consider sector-specific effects of globalization while designing policies to achieve inclusive growth in Pakistan.
\end{abstract}

Keywords: Globalization; Trade Openness; Employment

JEL Code: F6, F4, J6

\section{Introduction}

Globalization indicators including trade openness, foreign direct investment (FDI), workers' remittances inflows, and fluctuations in the exchange rate may all affect labor markets through changing size of the labor force, aggregate employment and wages(WTR, 2017; Adao et al., 2017; Ngandu, 2009). Trade openness may result increase in demand for labor depending on whether net demand of local goods by foreigners increases as a result of openness. FDI through establishing new businesses also generates demand for workers thus increasing employment in sectors where FDI inflows. Workers' remittances inflows and exchange rate also affect employment positively or negatively depending on the composition of employment in the country. At the sectoral level, workers' remittances affect agricultural employment negatively

${ }^{1}$ ssistant Professor (Visiting), Department of Economics, University of Gujrat, Punjab, Pakistan.

${ }^{2}$ Associate Professor, Department of Economics, University of Gujrat, Punjab, Pakistan ${ }^{3}$ Lecturer, Department of Business Management, Karakoram International University, Gilgit, Pakistan.

Corresponding Author: atif.ali@uog.edu.pk

Opten This work is Licensed under a Creative Commons Attribution-Noncommercial 4.0 International License $\propto$ (i)


due to moral hazard problems in remittances recipient families. Depreciation of local currency enhances employment in the agricultural sector due to a larger share of tradable commodities in the agriculture sector.

Pakistan is 6th most populous country of the world where more than 60 percent of the population is of less than 30 years of age and 2 million young people enter in the working-age population annually. According to Pakistan Labour Force Survey (201718), the overall unemployment rate in Pakistan is 5.8 percent but the unemployment rate for age group 15-24 years is more than 10 percent. To create employment opportunities for rising working-age population, the economy needs to grow consistently at the rate 6-8 percent annually. Average monthly wage of female workers in Pakistan is Rs. 7869 as compared to Rs. 12804 for male workers.

Pakistan's agriculture sector and industry jointly contribute less than 40 percent in GDP and services sector contribute more than 60 percent. Among the employed labor force (61.71 million) 38.5 percent belong to the agriculture sector, 23.7 percent to industry, and 37.8 percent to services sector of Pakistan (Pakistan Labour Force Survey, 201718). Table 01 shows that the total labor force increased from 28 million to 65.5 million during the period (1985-2018) thus recording 234 percent growth. Employed labor force increased from 26.29 million to 61.7 million during the same period, with growth of 234 percent. At the sectoral level, employment in the agriculture sector increased by 174.2 percent (net increase of 10.12 million) as compared to huge increase in employment in the services sector by 467.8 percent (net increase of 16.59 million).

There are many factors responsible for asymmetric employment growth in agriculture and other sectors of the economy. Globalization has also significantly contributed towards low job creation in the agriculture sector and shifts of jobs from agriculture to the services sector. Trade as a share of GDP moved from 27.7 percent in 1985 to 26.03 percent in 2018 but remained volatile during the period. Workers' remittances inflows in Pakistan significantly increased from US\$2.53 billion in 1985 to US\$20 billion in FY2018. FDI inflow increased to US\$ 3.5 billion in FY2018 from just US\$131 million in FY1985. Pak-rupee devalued against US\$ from RS15.92 in 1985 to RS164 in June 2019. In above scenario, it is pertinent to test the impact of globalization indicators on aggregate and agricultural employment in Pakistan. This would be useful for effective policy intervention to achieve the goal of inclusive and sustainable growth in Pakistan.

The current economic situation is not favorable for adequate job creation for youth bulge with domestic resources. Pakistan has signed USD \$6 billion Extended Fund Facility (EFF) program with International Monetary Fund (IMF). The major reason for signing the program with IMF was 8 percent inflation and less than 3 percent growth in FY2019. At the time of signing the program with IMF, the country had inadequate foreign exchange reserves (US\$ 8.8 billion), a volatile exchange rate approaching Rs154/US\$ on 22nd May 2019, and government borrowing from the central bank in 11 months approaching to Rs.5 trillion in FY2019. Tight monetary and fiscal policies to achieve macroeconomic stability will not be favorable for job creation due to expected 
slowness in the economic activity. In these circumstances, it is very important to exploit foreign resources to create employment opportunities for the rising working-age population. To support such policies, it is important to produce empirical evidence on the impact of globalization indicators on aggregate and sectoral employment in Pakistan.

This study investigates empirically the impact of globalization on aggregate and agricultural employment in Pakistan for the period 1986-2017. In this study, the variables used to reflect the globalization status of Pakistan include trade openness, FDI, exchange rate, and workers' remittances inflows. This study contributes in the existing literature significantly by providing evidence related to the impact of globalization on aggregate as well as agricultural employment in Pakistan. In the rest of the paper, Section 02 presents a review of literature on the subject. Section 03 discusses methodology and data sources. Section 04 and Section 05 present findings and implications of the study, respectively.

Table 1. Globalization and Labor Market Indicators of Pakistan

\begin{tabular}{|c|c|c|c|c|c|c|c|c|}
\hline & \multicolumn{4}{|c|}{ Labor Market Indicators } & \multicolumn{4}{|c|}{ Globalization Indicators( $\%$ of GDP) } \\
\hline $\begin{array}{l}\text { Year } \\
\mathrm{s}\end{array}$ & $\begin{array}{l}\text { Total } \\
\text { Labor } \\
\text { Force } \\
\text { (millions } \\
\text { ) }\end{array}$ & $\begin{array}{l}\text { Emplo } \\
\text { yed } \\
\text { Labor } \\
\text { Force } \\
\text { (millio } \\
\text { ns) }\end{array}$ & $\begin{array}{l}\text { Emplo } \\
\text { yed in } \\
\text { Agric } \\
\text { ulture( } \\
\text { millio } \\
\text { ns) }\end{array}$ & $\begin{array}{l}\text { Emplo } \\
\text { yed in } \\
\text { Servic } \\
\text { es(mil } \\
\text { lions) }\end{array}$ & $\begin{array}{l}\text { Trade } \\
\text { in } \\
\text { Good } \\
\mathrm{s}\end{array}$ & $\begin{array}{l}\text { Foreig } \\
\mathrm{n} \\
\text { Direct } \\
\text { Invest } \\
\text { ment(F } \\
\text { DI) }\end{array}$ & $\begin{array}{l}\text { Worker } \\
\text { s' } \\
\text { Remitta } \\
\text { nces } \\
\text { Inflows }\end{array}$ & $\begin{array}{l}\text { Exchan } \\
\text { ge Rate } \\
\text { (Rs/US } \\
\$ \text { ) }\end{array}$ \\
\hline 1985 & 28.0 & 26.3 & 13.6 & 4.5 & 33.2 & 0.42 & 8.14 & 15.9 \\
\hline 1990 & 31.8 & 30.7 & 15.7 & 5.2 & 38.9 & 0.61 & 5.01 & 21.7 \\
\hline 1995 & 34.2 & 32.3 & 15.1 & 6.3 & 36.1 & 1.19 & 2.82 & 31.6 \\
\hline 2000 & 40.4 & 37.3 & 18.1 & 6.9 & 28.1 & 0.41 & 1.45 & 53.6 \\
\hline 2005 & 46.8 & 43.2 & 18.9 & 8.9 & 35.3 & 2.01 & 3.90 & 59.5 \\
\hline 2010 & 57.2 & 53.8 & 24.2 & 11.6 & 32.9 & 1.13 & 5.46 & 85.1 \\
\hline 2015 & 61.0 & 57.4 & 24.3 & 11.5 & 27.6 & 0.36 & 7.12 & 102.7 \\
\hline 2018 & 65.5 & 61.7 & 23.8 & 21.1 & 26.0 & 1.19 & 6.41 & 109.8 \\
\hline
\end{tabular}

\section{Literature Review}

Both theoretical and empirical literature has identified various proxies of globalization including trade openness (measured as trade to GDP ratio, export to GDP ratio, import to GDP ratio, trade balance, terms of trade), FDI, exchange rate, remittances, and external debt. Theoretically, Hecksher-Ohlin (H-O) model is the basic tool which is used by researchers to determine the relationship between trade openness and labor market indicators. Existing empirical literature has tested the prevalence of $\mathrm{H}-\mathrm{O}$ model in case of both developed and developing countries. (Elijah, 2007) estimated effects of globalization on employment and wages in Nigeria. The study found that globalization 
has mixed effects (positive as well as negative) on Nigerian economies, such as the problem of income inequality has arisen and created wage gap among workers. Most of the less-skilled workers and some skilled workers have lost their jobs. On the positive side, globalization has created jobs in the informal sector more than the job loss in the formal sector. Policy implication of the study is that employees should be given training in order to assist them in sustaining their job. Moreover, Ghose (2008) investigated the relationship between globalization and employment for developing countries. The study found that in some countries globalization boosted employment and decreased productivity, while in others it has depressed employment and increased productivity growth. Globalization has systematically adverse effects on the informal sector, growth in output per worker has slowed in most of the developing economies during the period of globalization. Overall, the economies deriving positive growth effects from globalization have also received negative employment effects as well. Whereas, a few studies found that openness positively affects the relative demand for skilled workers (ASALEYE, OKODUA, OLONI, \& OGUNJOBI, 2017; Charfeddine \& Mrabet, 2015)

The impact of FDI on recipient economies vary from one country to the other depending upon the characteristics of the country, sectors and type of the investment inflow. (Hisarciklilar, Gultekin-Karakas, \& Asici, 2014) have checked the impact of FDI on Turkish employment on 19 sectors for the period 2000-2008. The study used Panel Vector Autoregressive and Feasible Generalized Least Square (FGLS) and results revealed that FDI creates new employment opportunities but the level of job creation is too low for multiple factors including lack of structural transformation, lack of capital accumulation, uneven distribution of FDI in sectors etc. Similarly, (Mickiewicz, Radosevic, \& Varblane, 2000) points out a positive relationship between FDI and employment in the Hungary, Estonia, Czech Republic and Slovakia during economic transition (1993-1996) period.

Singh and Kumar (2018) have checked whether a good or moderate inflow of FDI helps in employment generation in India for the period 2010-17. The study found that FDI helps to increase employment in the agriculture sector but at low rate. FDI does not increase employment in the manufacturing sector and in the services sector it increases employment less than 30\%. (Wei, 2013) found no relationship between FDI and aggregate employment for Chinese economy. The relationship between FDI and employment by sectors differed in the primary sector where it creates jobs as compared to the secondary sector where the relationship was insignificant. In the tertiary sector, FDI and employment were found associated negatively. (Golejewska, 2002) checked the impact of FDI on sectoral employment for Poland and argued that FDI asymmetrically affects sectoral employment, on the one hand, it raised employment in glass and textile industries on the other hand it reduced employment in industries of apparel and footwear.

Most of the studies we have reviewed show the positive effect of exchange rate depreciation on employment (Hua, 2007; Ngandu, 2009; Nucci \& Pozzolo, 2004), with few exceptions where (Filiztekin, 2004) has found a negative effect of exchange rate 
depreciation on the employment of Turkish economy. Moreover, an overall conclusion from sectoral studies suggested that the effect of depreciation depends on the nature of the sector. Exchange rate depreciation enhances employment in tradeable sectors whereas worsens in non-tradable sectors (Ngandu, 2009).

Vast body of existing empirical literature on the effect of remittances on employment used household-level data. (Airola, 2008) found that in the case of Mexico people spent few hours in the labor market after receiving remittances. (Amuedo-Dorantes \& Pozo, 2004) have suggested that there exists no relationship between hours spent by Mexican men in the labor market and remittances inflows. Kim (2007) found that remittances has deteriorated the employment situation in Jamaica. The empirical studies using macroeconomic data to assess the relationship between employment and remittances are scant. Among a few available studies, Posso (2012) has determined the relationship in 66 developing countries (including regions of Middle East and Africa, Asua, Pacific, Latin America and Caribbean). The study concluded that there exists positive relationship between remittances and aggregate employment.

Empirical literature on the effect of globalization on employment in Pakistan is emerging. (Kiren \& Awan, 2018) checked the impact of FDI and Workers' remittances on employment by employing Johansen's cointegration and VECM and concluded that both have positive impact on employment of Pakistan. Similarly, (Malik, Chaudhry, \& Javed, 2011) concluded that there exists positive relationship between employment and FDI, but trade openness and exchange rate negatively affects job creation in Pakistan. Moreover, (Habib \& Sarwar, 2008) reached to similar conclusion by indicating positive employment effect of FDI whereas, negative affect of exchange rate on employment. Interestingly, (Rizvi \& Nishat, 2009) have assessed the relationship between FDI and employment for China, India and Pakistan. The study found insignificant relationship between FDI and employment in all three selected countries.

Above reviewed literature indicates that in case of Pakistan most of the studies relating to globalization and employment were conducted for aggregate employment. Further, studies were conducted using limited indicators of globalization. In this context, the current study has contributed in the literature by producing empirical evidence for aggregate and agricultural employment using a broad set of indicators of globalization.

\section{Methodological Issues}

This study has augmented the model originally developed by (Bhorat, Tian, \& Ellyne, 2014) to assess the impact of globalization on aggregate and agricultural employment in Pakistan. All variables in the model are in natural log form.

$$
\begin{aligned}
& \mathrm{Et}=\alpha 0+\alpha 1 \text { OPENt }+\alpha 2 \text { FDIt }+\alpha 3 \mathrm{ERt}+\alpha 4 \mathrm{WRIt}++\alpha 5 \mathrm{RGDPt}+\underset{\text { (Equation-01) }}{\alpha+\mu \mathrm{W}} \\
& \text { Where, }
\end{aligned}
$$


$\mathrm{E}=$ Employment level

$\mathrm{EA}=$ Employment in the agriculture sector

OPEN $=$ Trade openness measured as trade to GDP ratio

FDI $=$ Foreign direct investment inflow

$\mathrm{ER}=$ Exchange rate between Pak Rupee and US dollar

WRI= Workers' remittances inflows

RGDP= Real gross domestic product

WAGER $=$ Ratio of wages of male and female workers

$\mathrm{LF}=\mathrm{Labor}$ force

$\mu=$ Stochastic error term

The effect of OPEN on E is varying in the existing literature described through direct and indirect channels. On the direct side, demand for local goods replaced by imported goods erodes jobs for domestic workers. (Dutt, Mitra, \& Ranjan, 2009) and (Felbermayr, Prat, \& Schmerer, 2011) didn't find significant impact of trade openness on employment (or low effect) due to their focus on direct effect. Indirectly, cheap imported inputs cause increase in employment through production enhancement. Another positive effect of cheap imported inputs is through increase in disposable income of domestic consumers resulting increase in their spending. This leads to high demand for domestic goods thus increasing demand for labor and employment. (Caliendo, Dvorkin, \& Parro, 2015) and (Adao, Arkolakis, \& Esposito, 2017) concluded significant impact of trade openness on employment and wages.

There are both positive as well as negative effects of FDI on employment in host countries. Establishment of new firms create employment. Additionally, FDI might generate new jobs within relevant sub sectors where FDI is coming. Once labor demand rises with the arrival of FDI in host country, it enhances employment though multiplier effect. However, foreign firms may also replace domestic firms due to increased international competition thus no change in the level of employment, employment might be skewed, or even closure of the acquired firm may reduce employment (UNCTAD, 1994).

Literature has identified two channels through which exchange rate movements affect employment. An exchange rate depreciation enhances the export competitiveness of a particular country thus demand for labor and employment. While the second channel states that in response to the depreciation of exchange rate intermediate inputs become expensive thus offsetting the first channel. Hence, overall net effect of exchange rate 
movements on employment depends upon the exposure of the firms to foreign competition (Ngandu, 2009).

There are two opposing channels, which explain how remittances affect unemployment in capital constrained market. First, one is search effect, which demonstrates that remittances tend to increase the income of unemployed recipients that leads to a decrease in search intensity of new job. However, if the tax rate on wage income received by unemployed recipients is high than the difference between unemployed and employed will decrease, causing rise in unemployment. Second effect is investment effect according to which if some of the remittances are invested then firms would have the opportunity to increase the capital stock as this credit has relaxed capital constraints. Thus, firms will expand and cause unemployment to fall. Labor effect of remittances depends upon which effect is dominant, if investment effect is more important than search effect then the remittances will have decreasing impact on unemployment (Drinkwater, Levine, \& Lotti, 2003).

In the above model, impact of RGDP on employment depends on whether growth is inclusive or not. In case RGDP is not supporting creation of job opportunities then we can expect insignificant or even negative impact of RGDP on employment.

For the estimation of the above stated model, the current study used data period from 1986-2017. Data of OPEN, FDI, ER, RGDP and WRI is collected from World Development Indicators (WDI), World Bank, and data of WAGER and LF is obtained from Labor Force Surveys (LFS), Pakistan Bureau of Statistics. The limitation in selecting data up to 2017 is that Pakistan Bureau of Statistics (PBS) publishes Pakistan Labour Force Survey with a gap of one year and recent report was published for 201718.

\section{Results and Discussion}

To avoid spuriousness, we have checked the stationarity of variables before deciding a suitable estimation technique. Table 02 reports the results of the Augmented Dickey Fuller (ADF) test applied to check the stationarity of variables included in both models. Limitations and Future Research Prospects

There are some limitations in this study. This paper only explains the associations between CER and CFP, with moderators like organizational slack and industry competition, but there are many other moderators or mediators which can be studied like CEO characteristics. Future research should focus and search for deep systems and margins between CER and CFP. This study is conducted on just 50 companies from KSE 100 index, which is unable to reveal the advancement of CER and its cost. More sample size will provide more significant and clear results.

Table 2. Augmented Dickey Fuller (ADF) Test of Stationarity

\begin{tabular}{|c|c|c|}
\hline & At Level & At First Difference \\
\hline
\end{tabular}

Sukkur IBA Journal of Management and Business - SIJMB | Vol 8 No. 2 July - December 2021 @ Sukkur IBA University 


\begin{tabular}{|l|l|l|l|l|l|}
\hline Series & $\begin{array}{l}\text { With } \\
\text { intercept }\end{array}$ & $\begin{array}{l}\text { Intercept } \\
\text { and trend }\end{array}$ & With intercept & $\begin{array}{l}\text { Intercept and } \\
\text { trend }\end{array}$ & $\begin{array}{l}\text { Deci } \\
\text { sion }\end{array}$ \\
\hline E & $-0.1244(0)$ & $-1.9456(0)$ & $-5.9410(0)^{* * *}$ & $-5.8743(0)^{* * *}$ & $\mathrm{I}(1)$ \\
\hline EA & $-0.7164(0)$ & $-2.3050(0)$ & $-6.7202(0)^{* * *}$ & $-6.6208(0)^{* * *}$ & $\mathrm{I}(1)$ \\
\hline OPEN & $-2.751(0)^{*}$ & $-2.7078(0)$ & $-7.6852(0)^{* * *}$ & $-7.6351(0)^{* * *}$ & $\mathrm{I}(1)$ \\
\hline FDI & $-1.2578(0)$ & $-3.8682(3)$ & $-5.2724(0)^{* * *}$ & $-5.1860(0)^{* * *}$ & $\mathrm{I}(1)$ \\
\hline ER & $-2.2072(0)$ & $-0.8031(0)$ & $-4.6802(0)^{* * *}$ & $-4.1577(9)^{* * *}$ & $\mathrm{I}(1)$ \\
\hline RGDP & $-1.1011(1)$ & $-3.5351(4)$ & $-3.6010(0)^{* * *}$ & $-3.6094(0)^{* * *}$ & $\mathrm{I}(1)$ \\
\hline WRI & $0.5113(0)$ & $-1.1009(0)$ & $-4.7081(0)^{* * *}$ & $-4.9427(0)^{* * *}$ & $\mathrm{I}(1)$ \\
\hline WAGER & $-2.5903(0)$ & $-3.4332(1)^{*}$ & $-4.9735(3)^{* * *}$ & $-5.2166(3)^{* * *}$ & $\mathrm{I}(1)$ \\
\hline LF & $0.0221(0)$ & $-2.0624(0)$ & $-6.5948(0)^{* * *}$ & $-6.5053(0)^{* * *}$ & $\mathrm{I}(1)$ \\
\hline
\end{tabular}

$*, * *, * * *$ indicates the level of significance at $10 \%, 5 \%$ and $1 \%$, respectively. Values in parenthesis represent optimal lags in ADF selected through Schwarz Bayesian Criteria.

It can be observed from above the table that all the variables were integrated of order $\mathrm{I}(1)$. In presence of multiple variables in a model, having integration order I(1), Johansen's Cointegration test is considered most suitable. Based on the results produced by Johansen cointegration test (Trace and Maximum Eigen Value Tests) if variables incorporated in the model are cointegrated in the long run, then for confirmation of the long run relationship, Vector Error Correction Model (VECM) is applied. The first step in applying Johansen's cointegration test is to check optimal lag selection by applying Vector Autoregressive Regression (VAR) model. Table 03 presents results of different lag selection criteria based on VAR model.

Table 3. Lag Selection Criteria Based on VAR Model

\begin{tabular}{|c|c|c|c|}
\hline \multicolumn{4}{|c|}{ Model 1 (E, OPEN, FDI, ER, WRI, RGDP, WAGER, LF) } \\
\hline Lag Order & AIC & SIC & HQIC \\
\hline 0 & -18.92423 & -18.55780 & -18.80277 \\
\hline 1 & -31.30036 & $-28.00245^{*}$ & -30.20719 \\
\hline 2 & $-33.70331^{*}$ & -27.47394 & $-31.63845^{*}$ \\
\hline \multicolumn{4}{|c|}{ Model 2 (EA, OPEN, FDI, ER, WRI, RGDP, WAGER, LF) } \\
\hline Lag Order & AIC & SIC & HQIC \\
\hline 0 & -15.83856 & -15.47213 & -15.71710 \\
\hline 1 & -28.28047 & $-24.98257^{*}$ & -27.18731 \\
\hline 2 & $-29.96529^{*}$ & -23.73591 & $-27.90043^{*}$ \\
\hline
\end{tabular}

The optimal lags indicated with an asterisk (*) suggested by Schwarz Information Criterion (SIC) in both models was one whereas, Akaike Information Criterion (AIC) and Hannan-Quinn Information Criterion (HQIC) suggested two optimal lags to be included in the model. To save the degree of freedom, optimum lag selection used in the study was based on SIC. 
The results of the Johansen's cointegration test based on Trace and Maximum Eigenvalue statistics are reported in Table 04. The results showed the existence of longrun cointegration among the variables in both models. For model 1, Trace test revealed 3 cointegrating equations while the Maximum Eigenvalue test indicated 1 cointegration equation at five percent level of significance. For model 2, Trace and Maximum Eigenvalue indicated 3 and 2 cointegrating equations respectively.

Table 4. Results of Johansen's Cointegration Test

\begin{tabular}{|c|c|c|c|c|}
\hline \multicolumn{5}{|c|}{ Trace Test } \\
\hline & \multicolumn{2}{|l|}{ Variable E } & \multicolumn{2}{|l|}{$\begin{array}{l}\text { Model 02: } \\
\text { Variable EA }\end{array}$} \\
\hline $\begin{array}{l}\text { Hypothesized } \\
\text { No. of CE(s) }\end{array}$ & $\begin{array}{c}\text { Trace } \\
\text { Statistic }\end{array}$ & Prob.** & $\begin{array}{c}\text { Trace } \\
\text { Statistic }\end{array}$ & Prob.** \\
\hline None & $218.9333^{*}$ & 0.0000 & 230.1893* & 0.0000 \\
\hline At most 1 & $147.9547 *$ & 0.0011 & 152.5779* & 0.0004 \\
\hline At most 2 & $105.3552 *$ & 0.0093 & $102.3265^{*}$ & 0.0163 \\
\hline \multicolumn{5}{|c|}{ Maximum Eigenvalue Rank Test } \\
\hline & \multicolumn{2}{|l|}{ Variable E } & \multicolumn{2}{|l|}{$\begin{array}{l}\text { Model 02: } \\
\text { Variable EA }\end{array}$} \\
\hline $\begin{array}{l}\text { Hypothesized } \\
\text { No. of CE(s) }\end{array}$ & $\begin{array}{l}\text { Max-Eigen } \\
\text { Statistic }\end{array}$ & Prob.** & $\begin{array}{l}\text { Max-Eigen } \\
\text { Statistic }\end{array}$ & Prob.** \\
\hline None & 70.97864* & 0.0003 & $77.61141^{*}$ & 0.0000 \\
\hline At most 1 & 42.59948 & 0.1166 & $50.25137^{*}$ & 0.0177 \\
\hline At most 2 & 39.85429 & 0.0530 & 35.83051 & 0.1394 \\
\hline
\end{tabular}

DE $_{\mathrm{t}}=\alpha_{0}+\alpha_{1}$ DOPEN $_{\mathrm{t}}+\alpha_{2}$ DFDI $_{\mathrm{t}}+\alpha_{3}$ DER $_{\mathrm{t}}+\alpha_{4}$ DWRI $_{\mathrm{t}}++\alpha_{5}$ DRGDP $_{\mathrm{t}}+\alpha_{6}$ $\mathrm{DWAGER}_{\mathrm{t}}+\alpha_{7} \mathrm{DLF}_{\mathrm{t}}+\alpha_{8} \mathrm{ECM}_{\mathrm{t}-1}+\varepsilon_{\mathrm{t}}$

(Equation-02)

Table 5. Estimation Results

\begin{tabular}{|l|l|l|}
\hline Long Run Cointegration Results \\
\hline & $\begin{array}{l}\text { Model 1: Dependent } \\
\text { Variable E }\end{array}$ & $\begin{array}{l}\text { Model 2: Dependent } \\
\text { Variable EA }\end{array}$ \\
\hline OPEN & $-0.119(-6.1186)$ & $-0.108(-4.4307)$ \\
\hline FDI & $0.074(14.2016)$ & $0.024(3.6590)$ \\
\hline ER & $-0.279(-7.0493)$ & $0.361(7.1281)$ \\
\hline WRI & $0.054(6.5003)$ & $-0.081(-7.2231)$ \\
\hline RGDP & $-0.260(-4.8877)$ & $-0.377(-5.5961)$ \\
\hline WAGER & $-3.406(-13.1506)$ & $-3.026(-9.7868)$ \\
\hline LF & $0.245(3.0586)$ & $2.194(21.3864)$ \\
\hline Short Run Results & & \\
\hline
\end{tabular}




\begin{tabular}{|c|c|c|}
\hline & $\begin{array}{ll}\text { Model 1: } & \text { Dependent } \\
\text { Variable DE } & \end{array}$ & $\begin{array}{l}\text { Model 2: Dependen } \\
\text { Variable DEA }\end{array}$ \\
\hline $\mathrm{DE}(-1)$ & $0.779(2.0302)$ & --- \\
\hline $\operatorname{DEA}(-1)$ & --- & $-0.107(-0.7368)$ \\
\hline DOPEN & $0.105(2.3165)$ & $0.108(1.3345)$ \\
\hline DFDI & $-0.037(-2.8435)$ & $-0.012(-0.6106)$ \\
\hline DER & $-0.087(-1.1320)$ & $-0.274(-1.7617)$ \\
\hline DWRI & $0.037(1.8358)$ & $0.094(2.0161)$ \\
\hline DRGDP & $0.615(2.1229)$ & $-0.199(-0.3999)$ \\
\hline DWAGER & $0.381(0.9095)$ & $-0.732(-1.0183)$ \\
\hline DLF & $-1.064(-2.2819)$ & $-0.976(-1.8037)$ \\
\hline DUM1991 & $-0.056(-2.9579)$ & $-0.133(-3.9056)$ \\
\hline ECM(-1) & $-0.59(-3.5977)$ & $-0.93(-4.5459)$ \\
\hline \multicolumn{3}{|l|}{ Diagnostic Tests } \\
\hline $\mathrm{R}^{2}$ & 0.591 & 0.711 \\
\hline F-statistics & 3.042 & 5.180 \\
\hline $\begin{array}{l}\text { Jarque-Bera Normality } \\
\text { Test (Probability) }\end{array}$ & $3.1083(0.2113)$ & $0.5744(0.7503)$ \\
\hline $\begin{array}{lr}\text { Breusch-Godfrey } & \text { Serial } \\
\text { Correlation } & \text { LM } \\
\text { Test(Probability) } & \\
\end{array}$ & $0.3294(0.1712)$ & $0.2611(0.1213)$ \\
\hline $\begin{array}{l}\text { ARCH } \\
\text { Heteroskedasticity } \\
\text { Test(Probability) }\end{array}$ & $0.6457(0.6322)$ & $0.5415(0.5257)$ \\
\hline CUSUM & Stable & Stable \\
\hline CUSUM SQ & Stable & Stable \\
\hline
\end{tabular}

Results reported in Table 05 show that coefficients of explanatory variables, in the long run, are statistically significant in both models. OPEN has a negative effect on aggregate and agricultural employment with coefficients 0.12 and 0.11 . It means that aggregate and agricultural employment decreased by 0.12 and 0.11 percent respectively due to 1 percent increase in openness. This finding is consistent with (Elijah, 2007) and (Malik et al., 2011). The coefficients of FDI in both models were positive, however, their values were small. Due to 1 percent surge in FDI, aggregate employment rose by 0.074 percent and agricultural employment increased by just 0.024 percent. These results are consistent with the findings of existing literature (Habib \& Sarwar, 2008; Hisarciklilar et al., 2014; Kiren \& Awan, 2018).

Interestingly, ER and WRI are affecting aggregate and agricultural employment differently. Exchange rate depreciation discouraged aggregate employment; however, it had positive effect on agricultural employment during the data period. The results showed that due to one percent depreciation of Pak-rupee against US dollar, aggregate Sukkur IBA Journal of Management and Business - SIJMB | Vol 8 No. 2 July - December 2021 ๑ Sukkur IBA University 
employment reduced by 0.28 percent, whereas, agricultural employment increased by 0.36 percent. These results are supported by findings of (Filiztekin, 2004) and (Ngandu, 2009). WRI is found responsible for promoting aggregate employment while it decreased agricultural employment during data period. Due to 1 percent increase in workers' remittances, aggregate employment increased by 0.054 percent while agricultural employment fell by 0.081 percent. These results are consistent with the findings of (Chami, Ernst, Fullenkamp, \& Oeking, 2018) which stated that farmers' effort towards agricultural production decrease with workers' remittances inflows.

\section{Model 01:}
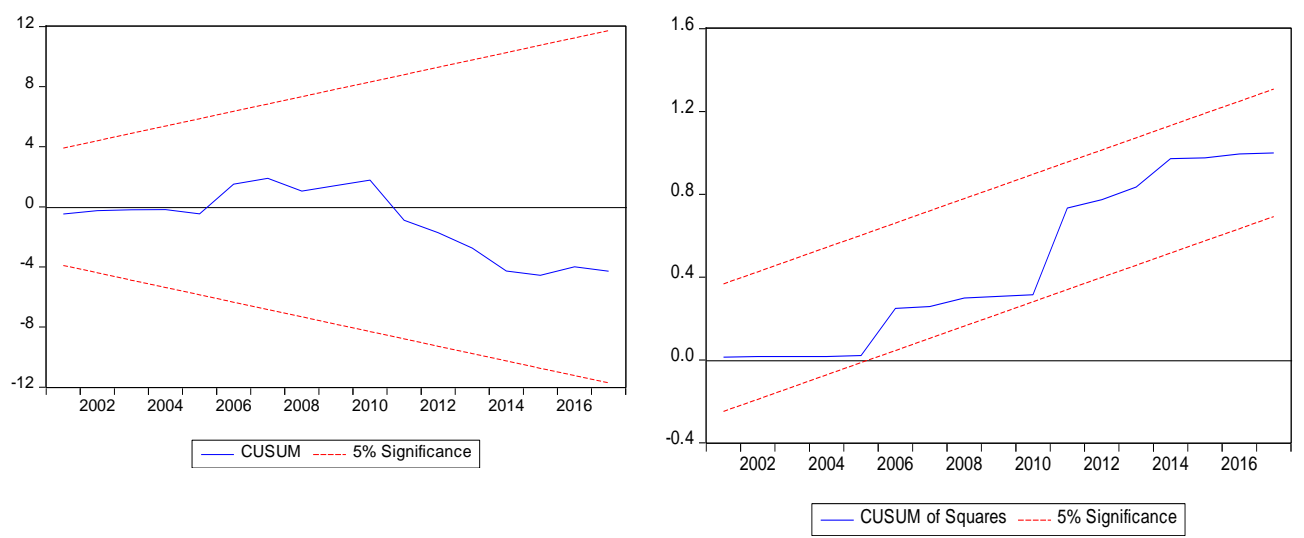

\section{Model 02:}
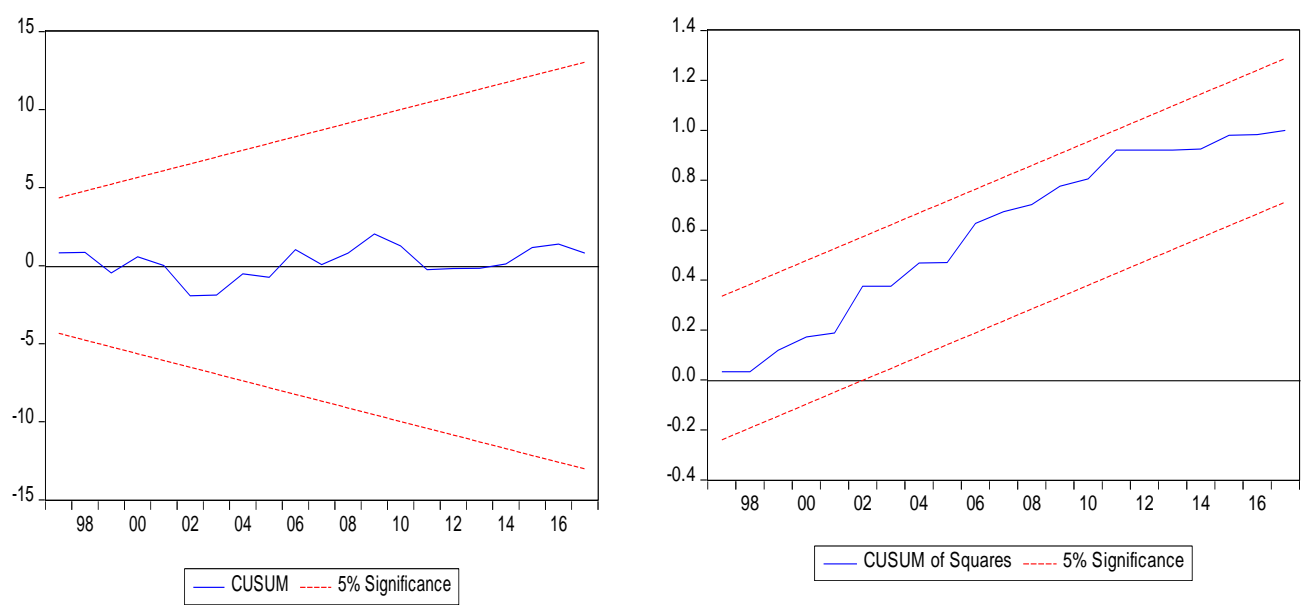

Figure 1. CUMSUM and CUMSUMSQ Tests of Model Stability

Real GDP is not supporting job creation at the aggregate level and in the agriculture sector too, which is an indication of non-inclusive economic growth in Sukkur IBA Journal of Management and Business - SIJMB | Vol 8 No. 2 July - December 2021 @ Sukkur IBA University 
Pakistan. The sign of coefficient of gender-based wage gap is also negative in both models showing that as gender-based wage gap increases, aggregate and agricultural employment decreases. Labor force positively affects aggregate and agriculture employment in Pakistan.

The coefficient of ECM (-1) in Error Correction Model (Equation02) reported in both models is negative and significant with value ranging between 0 and -1 . This implies that error correction process converges to equilibrium with the speed of 59 percent and 93 percent in model 1 and model 2 respectively. The significance of negative coefficients of lagged error term is also considered confirmation of long term relationship.

Measure of goodness of fit $\left(\mathrm{R}^{2}\right)$ shows how much variation in the dependent variable is being explained by variation in independent variables incorporated in the model. In both models, considerable variation (59 percent and 71 percent, respectively) in dependent variables is explained by explanatory variables. F-statistics shows overall significance of the models as reported in Table 05.

Standard diagnostic tests have been applied on both models to establish the validity of estimation results. Jarque-Bera Histogram test is applied to check normality of residuals. In Table 05, values in the parenthesis of test statistics show that probabilities are greater than 0.05 thus error terms are normally distributed in both models. Breusch Godfrey test is applied to check serial correlation among errors and results show that no serial correlation is present in any of the models. Breusch-PeganGodfrey test is applied to examine presence of heteroskedasticity problem in estimated residuals. Results indicate that no heteroskedasticity is present in any of the model. CUSUM and CUSUM SQ tests were used to check stability of the model, results of both tests in Figure 01 show that models were stable.

\section{Conclusion}

This study has investigated the impact of globalization on aggregate and agricultural employment in Pakistan for the period 1986-2017. The results show that trade liberalization has a negative and significant effect on aggregate and agricultural employment in Pakistan whereas FDI has a positive and significant effect with low coefficients on both aggregate and agricultural employment. Exchange rate depreciation affects agricultural employment positively due to large share of tradeable in agriculture sector of Pakistan. Real GDP affects aggregate and agricultural employment negatively in Pakistan during the data period of the study. This shows economic growth in Pakistan is not inclusive and employment enhancing. Gender-based wage gap also affects aggregate and agricultural employment negatively showing that gender-based discrimination in the labor market is not beneficial for the economy. On the basis of the findings of the study, it may be concluded that the impact of globalization needs to be observed at a sectoral level to avoid inequality through balanced employment creation. Policymakers need to focus on agricultural employment to achieve inclusive and sustainable growth in Pakistan.

Sukkur IBA Journal of Management and Business - SIJMB | Vol 8 No. 2 July - December 2021 C Sukkur IBA University 
Author Contributions: This paper is based on PhD thesis of Dr. Moniba Sana entitled "A Sectoral Study

on Globalization, Gender Based Gaps and Employment Shifts in Pakistan" conducted under the

supervision of Dr. Atif Ali Jaffri. Dr. Asad Ullah contributed in arranging literature review, formatting and

revision of the article for publication.

Data Availability Statement: The study used published time series data collected from World

Development Indicators (WDI), World Bank, and from Labor Force Surveys (Various Issues), Pakistan

Bureau of Statistics. The limitation in selecting data up to 2017 is that Pakistan Bureau of Statistics (PBS)

publishes Pakistan Labour Force Survey with a gap of one year and recent report was published for

2017-18.

Conflict of Interest: there is no any conflict of interest

Funding Information: Not Applicable as paper is based on $\mathrm{PhD}$ thesis of first author.

\section{References}

Adao, R., Arkolakis, C., \& Esposito, F. (2017). Trade, Agglomeration Effects, and Labor Markets: Theory and Evidence. Retrieved from

Airola, J. (2008). Labor supply in response to remittance income: The case of Mexico. The Journal of Developing Areas, 41(2), 69-78.

Amuedo-Dorantes, C., \& Pozo, S. (2004). Workers' remittances and the real exchange rate: a paradox of gifts. World development, 32(8), 1407-1417.

ASALEYE, A. J., OKODUA, H., OLONI, E. F., \& OGUNJOBI, J. O. (2017). Trade Openness and Employment: Evidence from Nigeria. Journal of Applied Economic Sciences, 12(4), 1194-1209.

Bhorat, H., Tian, N., \& Ellyne, M. (2014). The real exchange rate and sectoral employment in South Africa: Development Policy Research Unit.

Caliendo, L., Dvorkin, M., \& Parro, F. (2015). The impact of trade on labor market dynamics. Retrieved from

Chami, M. R., Ernst, E., Fullenkamp, C., \& Oeking, A. (2018). Are remittances good for labor markets in LICs, MICs and Fragile States? : International Monetary Fund.

Charfeddine, L., \& Mrabet, Z. (2015). Trade liberalization and relative employment: further evidence from Tunisia. Eurasian Business Review, 5(1), 173-202.

Drinkwater, S., Levine, P., \& Lotti, E. (2003). The labour market effects of remittances: Hamburgisches Welt-Wirtschafts-Archiv.

Dutt, P., Mitra, D., \& Ranjan, P. (2009). International trade and unemployment: Theory and cross-national evidence. Journal of International Economics, 78(1), 32-44.

Sukkur IBA Journal of Management and Business - SIJMB | Vol 8 No. 2 July - December 2021 @ S Sukkur IBA University 
Elijah, O. A. (2007). Effects of economic globalisation on employment trend and wages in developing countries: Lessons from Nigeria experiences. Retrieved from

Felbermayr, G., Prat, J., \& Schmerer, H.-J. (2011). Trade and unemployment: What do the data say? European Economic Review, 55(6), 741-758.

Filiztekin, A. (2004). Exchange rates and employment in Turkish manufacturing. Faculty of Arts and Social Sciences, Sabanci University, Istanbul.

Golejewska, A. (2002). Foreign direct investment and its employment effects in Polish manufacturing during transition. Retrieved from

Habib, M. D., \& Sarwar, S. (2008). Impact of foreign direct investment on employment level in Pakistan: A time series analysis. Journal of Law, Policy and Globalization, 10, 46-56.

Hisarciklilar, M., Gultekin-Karakas, D., \& Asici, A. A. (2014). Can FDI be a panacea for unemployment?: The Turkish case Labor and employment relations in a globalized world (pp. 43-70): Springer.

Hua, P. (2007). Real exchange rate and manufacturing employment in China. China Economic Review, 18(3), 335-353.

Kiren, K., \& Awan, A. G. (2018). The Role of Globalization in employment generation: Evidence from Pakistan. Global Journal of Management, Social Sciences and Humanities, 4(1), 111-132.

Malik, S., Chaudhry, I. S., \& Javed, H. I. (2011). Globalization and Employment: Evidence from Pakistan. Pakistan Journal of Social Sciences, 31(2), 215-226.

Mickiewicz, T., Radosevic, S., \& Varblane, U. (2000). The value of diversity: Foreign direct investment and employment in Central Europe during economic recovery. Retrieved from

Ngandu, S. N. (2009). The impact of exchange rate movements on employment: The economywide effect of a rand appreciation. Development Southern Africa, 26(1), 111-129.

Nucci, F., \& Pozzolo, A. F. (2004). The Effects of Exchange Rate Fluctuations on Employment: An Analysis with Firm Level Panel Data. Retrieved from

Rizvi, S. Z. A., \& Nishat, M. (2009). The impact of foreign direct investment on employment opportunities: Panel data analysis: Empirical evidence from Pakistan, India and China. The Pakistan Development Review, 48(4), 841-851.

Wei, Y. (2013). The effect of FDI on employment in China. (Master of Arts), Iowa State University.

Sukkur IBA Journal of Management and Business - SIJMB | Vol 8 No. 2 July - December 2021 @ Sukkur IBA University 